\title{
Recensões
}

\section{Santos, Ana Cristina (2013), Social Movements and Sexual Citizenship in Southern Europe. Basingstoke: Palgrave Macmillan, 240 pp.}

Social Movements and Sexual Citizenship in Southern Europe constitui um estudo de grande fôlego sobre o associativismo Lésbico, Gay, Bissexual, Transgénero e Queer (LGBTQ) português, sendo que a autora já anteriormente tinha lançado as suas bases em $A$ lei do desejo. Direitos bumanos e minorias sexuais em Portugal (2005), ${ }^{1}$ prosseguindo-o depois na sua tese de doutoramento, que a obra em análise largamente reflete. Não será doravante legítimo, para quem trate do tema, deixar de passar por Social Movements and Sexual Citizenship in Southern Europe. Convém assinalar que esta obra transcende em muito as limitações geralmente inerentes aos trabalhos académicos. E isto não apenas pela sua excelência intrínseca, mas porque vem numa sequência, que é tão biográfica como teorética, absolutamente coerente com toda a pesquisa anterior de Santos - desde A lei do desejo, posteriormente prosseguida, até à conceção do projeto "INTIMATE - Cidadania, cuidado e escolha: a micropolítica da intimidade na Europa do sul", financiado pelo European Research Council, cujas bases teóricas se pode depreender que já se encontram, em grande medida, em Social Movements and Sexual Citizenship in Southern Europe. Teoricamente, o ponto de partida da obra encontra-se na intersecção dos estudos sobre os movimentos sociais, os estudos Gay, Lésbicos e Queer (GLQ) e os estudos sobre a cidadania sexual. Paralelamente, os movimentos e os contextos LGBT de Espanha e de Itália foram sobretudo utilizados como contrapontos mais do que fontes de dados comparativos para o estudo do associativismo LGBT português. Está longe de ser abundante a literatura que o investiga e Ana Cristina Santos é a única autora que o abordou extensamente no seu conjunto e da forma mais minuciosa e aprofundada. Mais, além da "tese-objeto-académico" e acima de tudo, é a única que detém o mérito de ter formulado uma tese teórica de fundo sobre ele. Com efeito, após contextualizar o associativismo LGBT português no(s) âmbito(s) mais vasto(s) das mudanças políticas, legais e culturais no próprio país, bem como a nível global, a autora defende que, em Portugal especificamente, o movimento LGBT transcende de algum modo a clássica dicotomia entre assimilacionismo/integracionismo e radicalismo/confrontacionalismo, apresentando caraterísticas singulares que definem um ativismo sincrético que uma abordagem teórica se tem de obrigar a considerar para o poder compreender cabalmente, evitando os enviesamentos decorrentes da aplicação à realidade nacional de grelhas teóricas formuladas em função de outros contextos históricos: "O ativismo sincrético é uma nova abordagem decorrente do seu uso combinado de estratégias orientadas para fins, que de outro modo poderiam ser vistos como incompatíveis. Aquilo que o impulsiona é um alvo estabelecido,

\footnotetext{
${ }^{1}$ Santos, Ana Cristina (2005), A lei do desejo. Direitos humanos e minorias sexuais em Portugal. Porto: Afrontamento, 203 pp.
} 
de preferência a uma posição ideológica. $\mathrm{O}$ fundamento sobre que assenta o ativismo sincrético advém daquilo que os ativistas constroem como objetivos atingíveis, os quais determinam as estratégias empregadas e os ativistas percecionam o sucesso do movimento com base nesses objetivos previamente definidos" (Santos, 2013: 157). Se algum reparo de monta houvesse a fazer, seria algo que inegavelmente afeta toda a atual pesquisa das ciências sociais e humanas sobre o movimento LGBT, e que consiste no facto de elas terem de confiar de algum modo em pressupostos não provados ou análises ainda consideravelmente superficiais ou insuficientes na sua generalidade sobre questões como o verdadeiro sentido e alcance da religião na sociedade portuguesa (e nas próprias pessoas LGBT). Ou da história da perseguição legal da homossexualidade, ou das formas e modalidades da homofobia na sociedade portuguesa e da homofobia internalizada na comunidade LGBT, para dar apenas estes exemplos. Nem por isso a investigação fica comprometida, porém: trabalho para quem o faça e com exigência não inferior à da presente obra. A autora retira duas conclusões de fundo que resultam da exploração teórica respeitante aos movimentos sociais. Primeiro, que o estudo destes requer uma moldura teórica capaz de dar conta da diversidade dos seus atores e estratégias, ao invés de construir os impactos dos movimentos segundo narrativas lineares, o que leva a autora à crítica das explicações sociológicas dominantes quanto à fragilidade histórica e à ineficácia dos movimentos sociais em Portugal, que, afinal, a academia acaba por falsamente reiterar, na medida em que essencialmente os desvaloriza (p. 176). Segundo, que é imprescindível levar em consideração as contradições e tensões intrínsecas ao próprio associativismo LGBT, as quais, no entanto, acabam por fazer com que o ativismo beneficie com a sua constitutiva conflitualidade, que dinamiza o seu impacto nas esferas política, jurídica e mediática, sem ter de depositar a sua exclusiva confiança numa forçada homogeneidade estratégica e ideológica (p. 177). Ana Cristina Santos, que sempre prestou uma atenção crucial à relação entre a investigação académica e o ativismo político, tem com este livro um contributo incontornável para a esclarecer, sem excessivas complacências tanto para uma como para o outro. É importante destacar o facto de Santos compor o quadro teórico e histórico a partir do qual é possível empreender uma análise extremamente produtiva do processo que levou a que o nosso país tenha sido pioneiro na aprovação de uma lei que permite o casamento entre pessoas do mesmo sexo, ainda que o âmbito da obra abranja sobretudo uma época anterior e se refira a esse processo de forma muito breve; e ainda que a lei do casamento tenha vindo a marcar uma alteração histórica radical no quadro de funcionamento do associativismo LGBT em Portugal tal como ele foi estudado pela autora.

António Fernando Cascais

\section{Batista, Vera Malaguti (org.) (2012), Loïc Wacquant e a questão penal no capitalismo neoliberal. Rio de Janeiro: Revan, 317 pp. Tradução de Sérgio Lamarão.}

Os ensaios reunidos na obra apresentam uma abordagem da sociologia criminal-punitiva dos mais variados matizes, fazendo com que a leitura completa possa prescindir da ordem em que os textos foram apresentados. Excetuando-se, é claro, 